\title{
Apoptosis Induction in Human Leukemia Cell Lines by Gold Nanoparticles Synthesized Using the Green Biosynthetic Approach
}

\author{
Farideh Namvar, ${ }^{1,2}$ Heshu Sulaiman Rahman, ${ }^{3,4,5}$ \\ Rosfarizan Mohamad, ${ }^{1,6}$ Abdullah Rasedee, ${ }^{3}$ Swee Keong Yeap, \\ Max Stanley Chartrand, ${ }^{7}$ Susan Azizi, ${ }^{8}$ and Paridah Mohd Tahir ${ }^{1}$ \\ ${ }^{1}$ Institute of Tropical Forestry and Forest Products, Universiti Putra Malaysia (UPM), 43400 Serdang, Selangor, Malaysia \\ ${ }^{2}$ Islamic Azad University, Mashhad Branch, Mashhad, Iran \\ ${ }^{3}$ Department of Veterinary Laboratory Diagnosis, Faculty of Veterinary Medicine, Universiti Putra Malaysia (UPM), \\ 43400 Serdang, Selangor, Malaysia \\ ${ }^{4}$ Institute of Bioscience, Universiti Putra Malaysia (UPM), 43400 Serdang, Selangor, Malaysia \\ ${ }^{5}$ Department of Clinic and Internal Medicine, College of Veterinary Medicine, University of Sulaimani, Sulaymani Nwe, \\ Street 27, Zone 11, Sulaimani, Kurdistan Region, Iraq \\ ${ }^{6}$ Faculty of Biotechnology and Biomolecular Sciences, Universiti Putra Malaysia (UPM), 43400 Serdang, Selangor, Malaysia \\ ${ }^{7}$ DigiCare Behavioral Research, Casa Grande, AZ, USA \\ ${ }^{8}$ Department of Chemistry, Faculty of Science, Universiti Putra Malaysia (UPM), 43400 Serdang, Selangor, Malaysia
}

Correspondence should be addressed to Farideh Namvar; farideh.namvar@gmail.com

and Heshu Sulaiman Rahman; heshusr77@gmail.com

Received 15 June 2015; Accepted 23 August 2015

Academic Editor: Wolfgang Fritzsche

Copyright (C) 2015 Farideh Namvar et al. This is an open access article distributed under the Creative Commons Attribution License, which permits unrestricted use, distribution, and reproduction in any medium, provided the original work is properly cited.

Gold nanoparticles were grown on Sargassum muticum water extract (S-GNPs) using the green biosynthetic approach. The nanoparticles were characterized using UV-visible spectroscopy, zeta potential, and transmission electron microscopy (TEM). The resulting S-GNPs were spherical and crystalline with a size of $<10 \mathrm{~nm}$. The in vitro anticancer activity was demonstrated in human leukemia cell lines. The cancer cells were treated with different concentrations of S-GNPs, and calorimetric (MTT) assay used for the cytotoxicity test, which resulted in an $\mathrm{IC}_{50}$ value of $4.22 \pm 1.12,5.71 \pm 1.4,6.55 \pm 0.9$, and $7.29 \pm 1.7 \mu \mathrm{g} / \mathrm{mL}$ for each of the K562, HL-60, Jurkat, and CEM-ss cells, respectively. Thus, the K562 was selected for the next experiments. Furthermore, apoptosis induction was confirmed by Hoechst 33342, annexin V staining, and caspase-3/-9 activity tests. The cell cycle analysis exhibited a significant increase in the accumulation of S-GNPs treated cells at the sub-G1 phase, demonstrating the induction of apoptosis by S-GNPs. The nature of the inhibition of cancer cell growth by S-GNPs could open the way for further research in the design of green synthesis therapeutic agents, particularly in nanomedicine, for the treatment of cancer.

\section{Introduction}

Cancer, after heart disease and stroke, is the third leading cause of death in developing countries. According to WHO, cancers now account for approximately $13.3 \%$ of deaths and are expected to rise by at least $50 \%$ worldwide over the next 20 years [1]. Gold nanoparticles (GNPs) have great potential in the detection, diagnosis, and treatment of cancer [2].
For the preferred synthesis shape and size of GNPs there is a challenging and important mission with improvements of simple and flexible eco-friendly preparation methods. Typically, using organic solvents and chemical reducing agents for the synthesis of GNPs have raised environmental concerns due to the consequences of processing with toxic compounds [3]. The use of nontoxic and eco-friendly materials via green synthesis of metallic nanoparticles is 
being investigated to eliminate all possible biological risks in biomedical and pharmaceutical applications [3]. Many researchers are concentrating on bioactive natural products from plants or other sources, such as bacteria, fungi, and yeast, for the synthesis of metal nanoparticles [4-7]. Seaweed is a functional food and medicinal herb, the use of which dates back at least 5,000 years in ancient China [8].

Marine algae, in a wide variety of different species with different medicinal behaviors, can be divided into two groups, namely, microalgae and macroalgae. Marine macroalgae or seaweeds are classified according to their pigmentation into green (chlorophytes), red (rhodophytes), and brown (phaeophytes) [9]. Seaweeds are rich sources of lipids, minerals, and certain vitamins, and also several bioactive substances like polysaccharides, proteins, and polyphenols, with potential medicinal uses against cancer [10], oxidative stress [11, 12], inflammation [13], allergy [14], diabetes [15], thrombosis [16], obesity [17], lipidaemia [18], hypertension [19], and other degenerative diseases.

The history, chemistry, biomedical effects, and medical uses of seaweed species have been well documented and reviewed elsewhere [20-24]. Gold salts content within seaweed antioxidant could be reduced to obtain nanoparticles with specific properties offering potential applications in the biomedical field. In a previous study, we synthesized and characterized gold NPs using brown seaweed (Sargassum muticum) extract via the green method [25]. The genus Sargassum, a kind of brown algae comprising 150 species, is a tropical and subtropical brown seaweed in subtidal and intertidal areas [26]. The chemical and nutritional composition of seaweeds varies with individual species [27], habitats [28], and maturity and depends on the geographical origin or area of cultivation [29], seasonal [30], environmental [29], and physiological variations and water temperature $[30,31]$. The aim of this study was to investigate the cytotoxic effects of gold NPs prepared by green biosynthesis on various human cancer cell lines using a number of experimental methods.

\section{Materials and Methods}

2.1. Raw Material. Specimens of the Sargassum muticum seaweed from the coastal areas of Persian Gulf waters were collected, washed, and stored at $-20^{\circ} \mathrm{C}$.

2.2. Chemicals. Hydrogen tetrachloroaurate (III) $\left(\mathrm{HAuCl}_{4}\right.$. $3 \mathrm{H}_{2} \mathrm{O}, 99.98 \%$ ), used as a good precursor, was obtained from Sigma-Aldrich (St. Louis, MO, USA). All reagents in this study were of analytical grade.

2.3. Synthesis of S-GNPs. Stabilized and biocompatible SGNPs were prepared by suspending $1.0 \mathrm{~g}$ of seaweed in $100 \mathrm{~mL}$ of Milli-Q water. A volume of $50 \mathrm{~mL}$ from $0.1 \mathrm{M}$ $\mathrm{HAuCl}_{4}$ solution was added to $50 \mathrm{~mL}$ of the aqueous extract of $S$. muticum under continuous stirring at $45^{\circ} \mathrm{C}$. The solution changed color (light yellow to pink to cherry red) within one hour indicating the formation of S-GNPs. For complete reaction the obtained solution was left under stirring for a further one hour. The S-GNPs formed were separated from the residual seaweed by collecting the pellets after centrifugation at $6000 \mathrm{rpm} / 10$ minutes. The pellets were again suspended in double distilled water and the $\mathrm{pH}$ adjusted by adding $0.1 \mathrm{~mL}$ of phosphate buffer to the whole volume to physiological $\mathrm{pH}$.

2.4. UV-Vis Absorption Spectroscopy. UV-Visible spectra were recorded using a Lambda 25-Perkin Elmer (Waltham, MA, USA). The absorbance spectra were scanned in the range of 200-800 $\mathrm{nm}$ with a $1 \mathrm{~nm}$ interval at room temperature.

2.5. Zeta Potential (ZP) Measurement. The laser Doppler electrophoresis technique was applied to measure the particle electrostatic charge, in which $100 \mu \mathrm{L}$ of the particle solution was diluted with $1.5 \mathrm{~mL}$ of water and placed into a cuvette of the Zetasizer-nanoinstrument (Malvern, UK); the results are expressed as zeta potential (ZP). The measurements were performed in triplicate at a $\mathrm{pH}$ of $7.26 \pm 0.13$ to mimic physiological $\mathrm{pH}$.

2.6. Transmission Electron Microscopy (TEM). The TEM micrographs were obtained using an H-7100 electron microscope (Hitachi, Tokyo, Japan) instrument operated at an accelerating voltage of $120 \mathrm{KV}$. TEM samples were prepared by dispersing small quantities of the dried sample in distillate water and depositing a few drops of the resulting suspension on a copper grid.

2.7. Cell Culture Condition. The human leukemia cell lines K562 (chronic myelocytic leukaemia), Jurkat (acute lymphoblastic leukaemia), CEM-ss (acute lymphocytic leukaemia), and HL-60 (acute promyelocytic leukemia) were purchased from the American Type Culture Collection (ATCC) (Maryland, USA). All cell lines except HL-60 were maintained in RPMI-1640 (ATCC, USA) medium, supplemented with Lglutamine $(2 \mathrm{Mm}), 10 \%$ fetal bovine serum (FBS) (ATCC, USA) and 100 units $/ \mathrm{mL}$ penicillin, and $100 \mu \mathrm{g} / \mathrm{mL}$ streptomycin (Sigma Aldrich, USA). However, the basal medium for the HL-60 cell line was ATCC-formulated Iscove's Modified Dulbecco's Medium (IMDM) supplemented with fetal bovine serum to a final concentration of $20 \%$ and 100 units $/ \mathrm{mL}$ penicillin and $100 \mu \mathrm{g} / \mathrm{mL}$ streptomycin (Sigma Aldrich, USA). According to the ATCC protocol, all the cells were cultured and grown in $75 \mathrm{~cm}^{2}$ culture flasks (TPP, Switzerland) at $37^{\circ} \mathrm{C}$ in an incubator with a humidified atmosphere of $95 \%$ air and $5 \% \mathrm{CO}_{2}$. The cultures were frequently examined under an inverted microscope (Micros, Austria) for confluency and viability.

\subsection{Cytotoxicity Assay of S-GNPs toward Leukemia Cell Lines.} The cytotoxicity effects of S-GNPs at concentrations of 1 to $100 \mu \mathrm{g} / \mathrm{mL}$ of cancer cells were quantified using the MTT kit (Sigma Aldrich, USA) according to the instructions of the manufacturing company. Briefly, the cells were allowed to grow in a $75 \mathrm{~cm}^{2}$ cell culture flask until $90 \%$ confluent. Then, the cells were plated at an initial cell count of $1 \times$ $10^{3}$ cells per well, treated with various concentrations of SGNPs, and incubated for 72 hours at $37^{\circ} \mathrm{C}$ in a $5 \% \mathrm{CO}_{2}$. 
The MTT solution (Microculture Tetrazolium) (Sigma Aldrich, USA) $(25 \mu \mathrm{L})$ was added to each well, covered with aluminum foil, and incubated for an additional four hours in the dark to allow the metabolically active viable cells to convert the water-soluble yellow MTT solution into water insoluble purple formazan crystals. The optical density (OD) was measured at $570 \mathrm{~nm}$ using an ELISA plate reader (Universal Microplate reader) (Biotech Inc., USA). The $\mathrm{IC}_{50}$ value (concentration at which $50 \%$ of the cells are killed) was determined from the dose-response curve. The DMSO (0.1\%) was used as negative control. The assay was performed in triplicate.

\subsection{Cytotoxicity of S-GNPs toward Human Blood Mononu-} clear Cells. BD vacutainer (CPT) was used for the separation of primary lymphocytic cells from whole human blood. About $8.0 \mathrm{~mL}$ fresh blood was collected and mixed. The tube was then centrifuged in a horizontal rotor (swing-out head) (Hettich Zentrifugen, 32 R, Germany) for 15 minutes. Immediately after centrifugation, the buffy coat containing lymphocytes was gently aspirated with a Pasteur pipette and transferred into $25 \mathrm{~cm}^{2}$ cell culture flasks containing RPMI1640 medium (ATCC, USA) supplemented with L-glutamine ( $2 \mathrm{Mm}), 15 \%$ heat inactivated fetal calf serum (FCS) (ATCC, USA), 100 units/mL penicillin, and $100 \mu \mathrm{g} / \mathrm{mL}$ streptomycin (Sigma Aldrich, USA). The flask was incubated at $37^{\circ} \mathrm{C}$ in a $5 \%$ $\mathrm{CO}_{2}$ environment. After reaching $90 \%$ confluency, the cells were counted and plated in triplicate in 96-well microtitre plate (TPP, Switzerland). The antiproliferative effect of SGPNs on the lymphocytes was investigated for 24,48 , and 72 hours by trypan blue exclusion assay.

2.10. Morphological Assessment of Apoptosis. K562 cells $(1 \times$ $10^{5}$ cells $/ \mathrm{mL}$ ) were seeded on a $25 \mathrm{~cm}^{2}$ culture flask and treated with $\mathrm{IC}_{50}$ values of S-GNPs for 24, 48, and 72 hours. Later, the cells were collected and washed twice with cold PBS and stained in dark with $10 \mu \mathrm{L}$ Hoechst $33342(1 \mathrm{mM})$ and $5 \mu \mathrm{L}$ PI $(100 \mu \mathrm{g} / \mathrm{mL})$ on glass slides. The cells were visualized using an Olympus BHZ, RFCA microscope (Japan) equipped with a fluorescent light source with an excitation wavelength of $330 \mathrm{~nm}$ and a barrier filter of $420 \mathrm{~nm}$.

2.11. Annexin V-FITC Assay. Apoptosis was detected with an annexin V-FITC kit (Sigma Aldrich, USA) in accordance with the instructions of the manufacturer without any modification. Briefly, K562 cells at a concentration of $1 \times 10^{6}$ cells $/ \mathrm{mL}$ were exposed to S-GNPs for 6,12, and 24 hours. The cells were then collected and centrifuged at $1500 \mathrm{rpm}$ for five minutes to remove the media. Then, the cell pellets were washed twice with $1 \mathrm{~mL}$ PBS and centrifuged. Subsequently, the pellets were resuspended in $500 \mu \mathrm{L}$ ice-cold $1 \mathrm{x}$ binding buffer, to which $5 \mu \mathrm{L}$ of annexin V-FITC conjugate and $10 \mu \mathrm{L}$ of propidium iodide (PI) were added. The cells were gently vortexed and incubated for 15 minutes in the dark. Flow cytometric analysis was immediately conducted using laser emitting excitation light at $488 \mathrm{~nm}$ and a BD flow cytometer equipped with an Argon laser (Cyan ADP, DAKO, Glostrup, Denmark). Lastly, the analysis was carried out using Summit V4.3 software.
2.12. Cell Cycle Assay. The flow cytometer was used to support the cytotoxicity of S-GNPs towards K562 cells. Briefly, cells at a density of $2.5 \times 10^{6}$ cells $/ \mathrm{mL}$ were cultured with the S-GNPs and incubated for 12,24 , and 48 hours. The cells were harvested by centrifugation at $1500 \mathrm{rpm} / 5$ minutes and washed with $1 \mathrm{~mL}$ PBS. Subsequently, $600 \mu \mathrm{L}$ of $80 \%$ ice cold ethanol was added to the cell pellets drop by drop with continuous vortexing to prevent clumping and aggregation of cells and then kept at $20^{\circ} \mathrm{C}$ for five days. Then $1 \mathrm{~mL}$ PBS was added and spun down at $1500 \mathrm{rpm} / 5$ minutes. After that, the cell pellets were harvested again and washed twice with $1 \mathrm{~mL}$ PBS. Finally, collected cells were stained with a PBS staining buffer that contained $0.1 \%$ triton X-100, $10 \mathrm{mM}$ EDTA, $50 \mu \mathrm{g} / \mathrm{mL}$ RNAase A, and $3 \mu \mathrm{g} / \mathrm{mL}$ PI and incubated in the dark on ice for 20 minutes. Flow cytometric analysis was conducted using laser emitting excitation light at $488 \mathrm{~nm}$ using a BD FACSCalibur flow cytometer equipped with an Argon laser (BD, USA). Data analysis was performed using CellQuest Pro software.

2.13. Caspase Assay. The protease activity of caspases 3 and 9 in K562 cells was performed using a colorimetric assay kit (Gene script kit, code: L00289, Piscataway, NJ 08854, USA). About $2 \times 10^{6}$ cells were treated with S-GNPs at $\mathrm{IC}_{50}$ concentration and incubated for 24 and 48 hours, while the untreated cells incubated for 24 and 48 hours acted as control. Then, the cells were centrifuged for five minutes at $1500 \mathrm{rpm}$ to remove the media, following which the cells were washed twice with PBS, and centrifuged again at $1500 \mathrm{rpm} / 5$ minutes. The cell pellets were lysed by the addition of $50 \mu \mathrm{L}$ cold prepared lysis buffer, mixed well, and incubated on ice for one hour. The resulting cell lysate was centrifuged for one minute at $10,000 \mathrm{rpm}$ at $4^{\circ} \mathrm{C}$, and the supernatant was collected. The protein concentrations in each tube were quantified using the Bradford method. Then $50 \mu \mathrm{L} 2 \mathrm{x}$ reaction buffer was added to $50 \mu \mathrm{L}$ supernatant containing $200 \mu \mathrm{g}$ protein in each tube. Subsequently, $5 \mu \mathrm{L}$ caspase substrate was added, transferred to a 96-well plate, wrapped, and incubated at $37^{\circ} \mathrm{C}$ for four hours in dark. Finally, the samples were read at $405 \mathrm{~nm}$ in a microplate reader (Universal Microplate reader) (Biotech, Inc., USA). Data were presented as optical density (OD) (405 nm; mean SD) and a histogram was plotted.

2.14. Statistical Analysis. The experiments were done in triplicate and results were expressed as mean \pm SD. Statistical analyses were done using SPSS version 20.0 (SPSS Inc., Chicago, USA). Data were initially evaluated for homogeneity of variance and normality. Probability values of less than alpha $(P<0.05)$ were considered statistically significant.

\section{Results and Discussion}

Several natural products, including plants and herbs, have been successfully used in the efficient and rapid synthesis of different metal nanoparticles [3]. Such biomedically active components found in plants and herbal preparations have the advantage of being supportive in stabilizing nanoparticles without toxicity. Gold nanoparticles (GNPs) show potential 


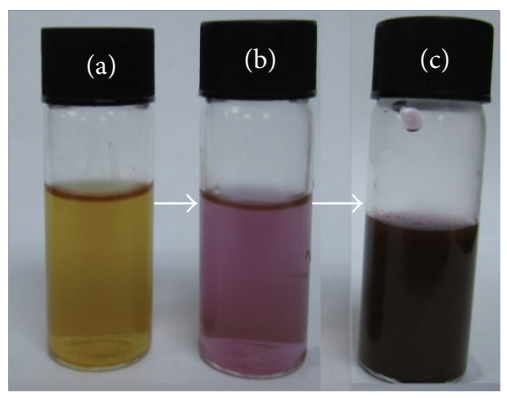

FIgURE 1: The color change of $S$. muticum aqueous extract at the beginning (a); $30 \mathrm{~min}$ (b); and $1 \mathrm{~h} \mathrm{(c)} \mathrm{after} \mathrm{synthesis} \mathrm{of} \mathrm{S-GNPs.}$

in many areas of biomedical sciences, including the treatment of cancer. Recently, natural products have been reported elsewhere for the green synthesis of metallic nanoparticles as reducing and stabilizing agents. Seaweed, one of the most commonly used medicinal extracts, has been acknowledged to exhibit anticancer activity in vitro and in vivo and in human clinical trials.

3.1. Synthesis of S-GNPs. In the current study, we synthesized Sargassum muticum stabilized gold nanoparticles via the one-step process, without the requirement of a stabilization or reducing agent. This method allows the production of gold nanoparticles within one hour (Figure 1). The gold nanoparticles generated through the seaweed-mediated process did not aggregate, suggesting that the cocktail of phytochemicals, including fucoxanthin, serve as excellent coatings on nanoparticles and thus provide strong protection from aggregation. The $\mathrm{AuCl}_{4}$ reduction was visually obvious from the changes in color from light purple to a ruby red color indicating the completed formation of S-GNPs, within one hour.

3.2. Characterization of S-GNPs. The presence of S-GNPs was confirmed by the characteristics of a surface plasmon resonance band of GNPs observed in the UV-Visible spectrum (Figure 2). The measured average zeta potential was $-35.8 \mathrm{mV}$ (Figure 3). This low value suggested that the S-GNPs solution was stable. The size distribution histogram showed mostly spherical shape GNPs with particle size distribution and mean diameter of $5.42 \pm 1.18 \mathrm{~nm}$ by TEM (Figure 4 ).

The fucoxanthin or polysaccharides, polyphenol, and other components within the Sargassum muticum not only result in the efficient reduction of gold salts to nanoparticles, but, in the same way as a proper capping agent, prevent them from aggregation. A very important requirement for nanoparticles biosynthesis for medical applications is aggregation resistance in different $\mathrm{pH}$ or in high ionic strength environments [32]. In the current study the S-GNPs stability was tested over time and did not show any obvious variation in particle shape and size even after several months' storage at room temperature; in addition, $\mathrm{S}-\mathrm{GNPs}$ in the $\mathrm{pH}$ range of 210 showed no discernible change in the intensity or position of the absorbance at $520 \mathrm{~nm}$.

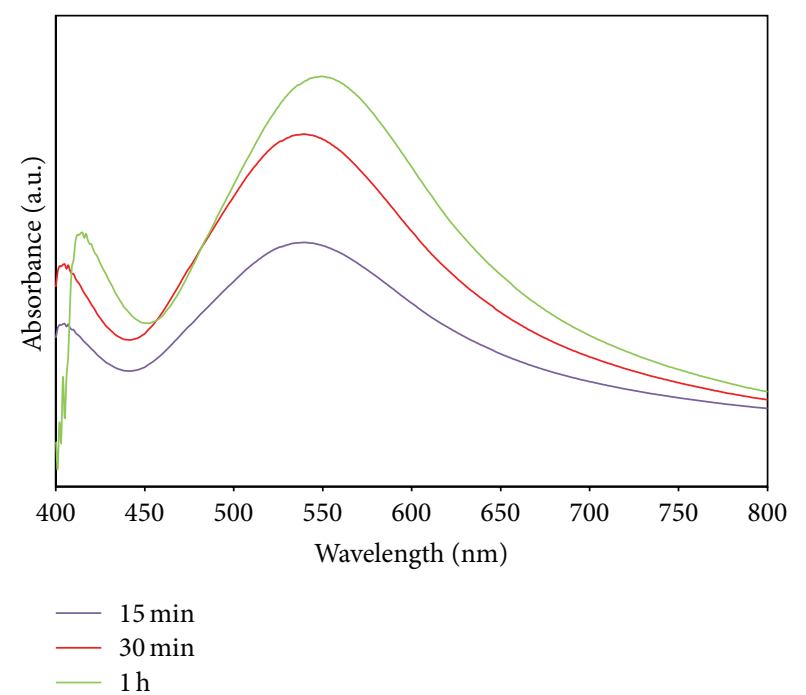

FIGURE 2: UV-Vis spectra of S-GNPs solution at different time of reaction.

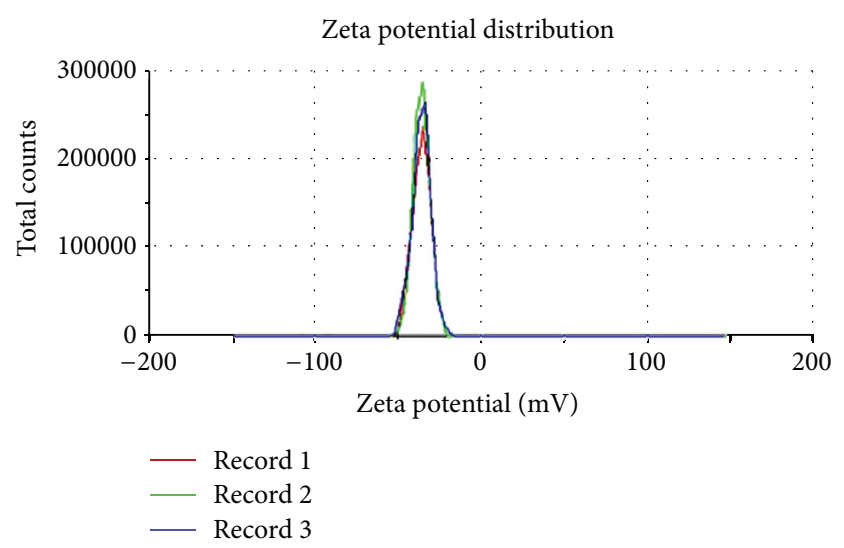

FIGURE 3: Zeta potential of biosynthesized S-GNPs.

Recently, another research group synthesized AgNPs and AuNPs with calcium alginate by using a photochemical approach via a UV light source [33]. One polysaccharide that is widely dispersed in the brown algae cell walls is alginic acid [34]. In this study calcium alginate gel was used as both a reducing agent and stabilizer and resulted in nanoparticles that were spherical in shape and crystalline with a size of $<10 \mathrm{~nm}$.

3.3. Cytotoxicity of S-GNPs. The results of the cytotoxicity were tested by observing the cellular morphological change, which showed that S-GNPs had no toxicity to the normal human blood mononuclear cells using trypan blue exclusion assay (Figure 5). S-GNPs, however, dose and time dependently inhibited the proliferation of the human leukemia cell lines. The $\mathrm{IC}_{50}$ values calculated for S-GNPs were 4.22 \pm 1.12 , $5.71 \pm 1.4,6.55 \pm 0.9$, and $7.29 \pm 1.7 \mu \mathrm{g} / \mathrm{mL}$ for $\mathrm{K} 562$, HL60, Jurkat, and CEM-ss cells, respectively, after treatment for 72 hours (Figure 6). The $\mathrm{IC}_{50}$ value calculated for pure Sargassum muticum methanol extract was $20.0 \pm 0.4 \mu \mathrm{g} / \mathrm{mL}$, 


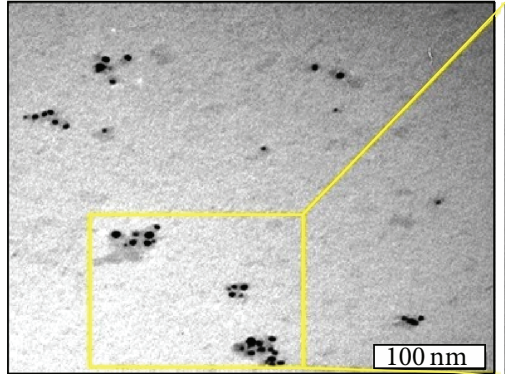

(a)

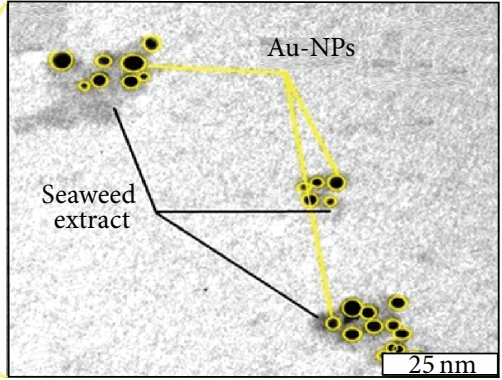

(b)

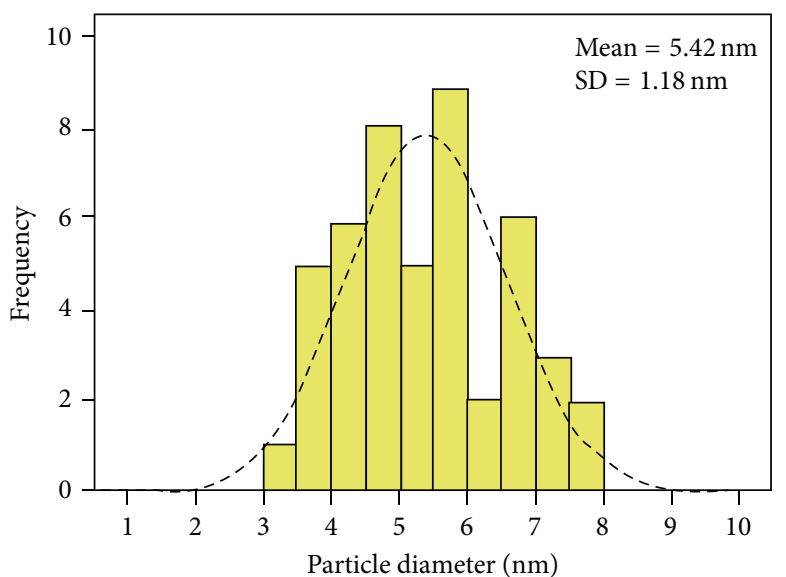

(c)

FIGURE 4: TEM images ((a)-(b)) and corresponding size distribution graph (c) of biosynthesized S-GNPs.

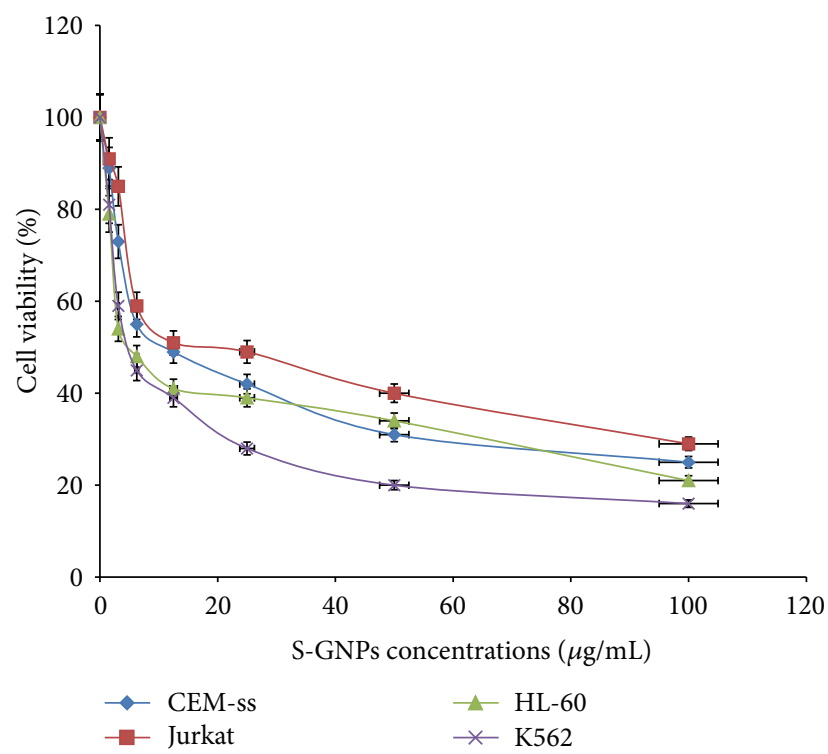

Figure 5: Cytotoxic effect of S-GNPs on CEM-ss, Jurkat, HL-60, and K562 cells assessed by MTT assay. Each point is the mean value of three replicates.

which is three times higher than the S-GNPs. It is also important to point out that the vast majority of Gold (I) and

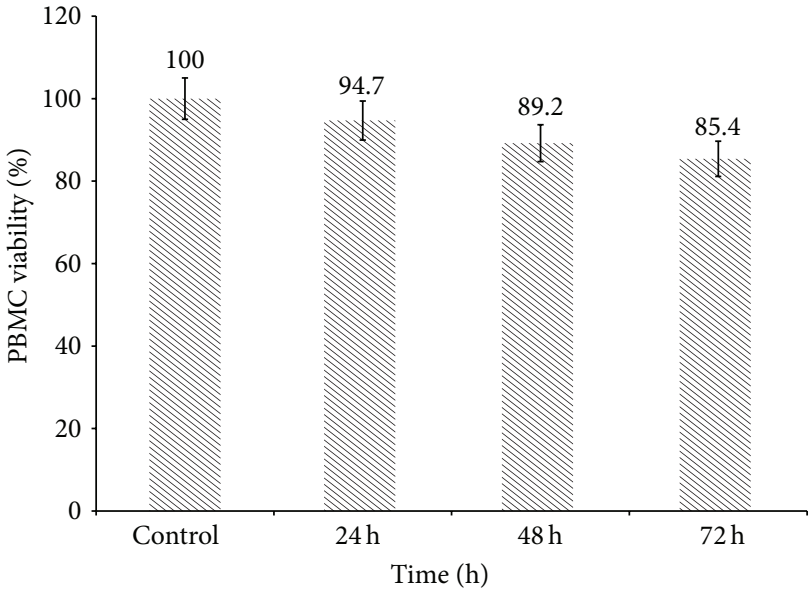

FIGURE 6: Cytotoxic effect of S-GNPs on human blood mononuclear cells. Values are expressed as mean \pm SD of three different experiments. The data has been analyzed using post hoc comparison testone way ANOVA, means compared with Tukey's- $b$ test.

Gold (III) compounds show varying degrees of cytotoxicity to a variety of cells [35].

These results clearly demonstrated that the biomedical active components such as fucoxanthin within seaweed provide a nontoxic coating on GNPs. The lack of any noticeable 
TABLE 1: Flow cytometric analysis of K562 cells after being treated with S-GNPs. The cells were stained with FITC-conjugated annexin V and PI and incubated at $37^{\circ} \mathrm{C}$ for 6,12 , and $24 \mathrm{~h}$, respectively.

\begin{tabular}{lcccc}
\hline Cell condition & Control & Treated/6h & Treated/12h & Treated/24h \\
\hline Viable cells & $96.5 \pm 0.55$ & $89.19 \pm 0.65$ & $80.21 \pm 0.11$ & $71.5 \pm 0.23$ \\
Early apoptosis & $1.81 \pm 0.15$ & $6.55 \pm 0.75^{*}$ & $9.00 \pm 0.33^{*}$ & $12.25 \pm 0.25^{*}$ \\
Late apoptosis/necrosis & $1.69 \pm 0.35$ & $4.26 \pm 0.05^{* *}$ & $10.79 \pm 0.40^{* *}$ & $16.25 \pm 0.19^{* *}$ \\
\hline
\end{tabular}

Values are expressed as mean \pm SD of three different experiments. The data has been analyzed using post hoc comparison test-one way ANOVA, means compared by Tukey's- $b$ test. $(*)$ : significant $(P<0.05)$ increased early apoptotic cells in S-GNPs treated groups compared to untreated controls. $(* *)$ : significant $(P<0.05)$ increased late apoptotic/necrotic cells in S-GNPs treated groups compared to untreated controls.

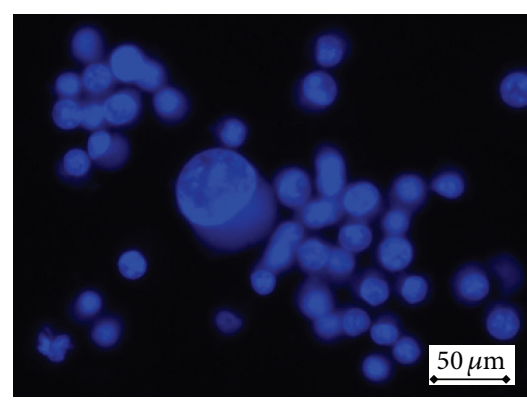

(a)

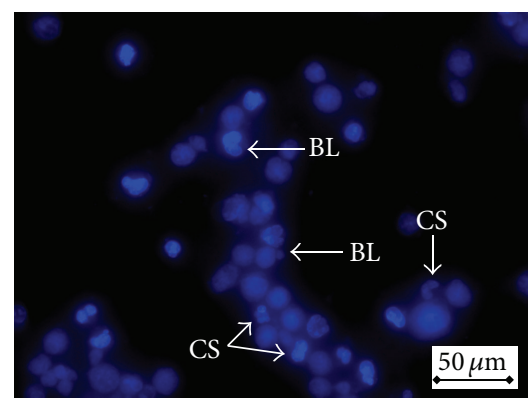

(c)

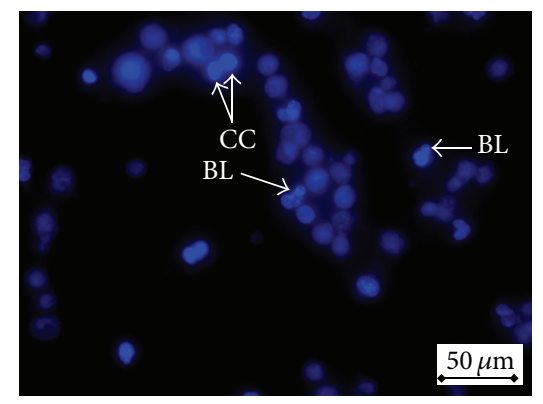

(b)

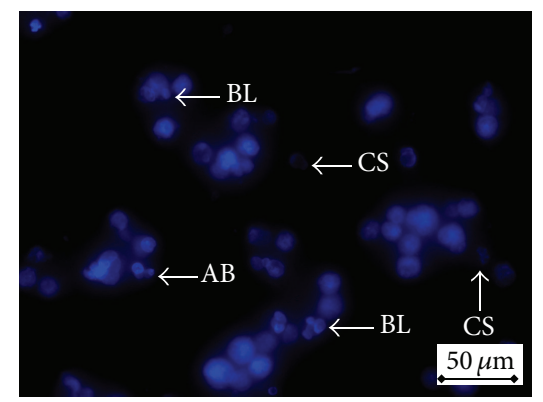

(d)

FIGURE 7: Fluorescent micrograph of Hoechst 33342 stained K562 cells that were treated with S-GNPs. (a) Untreated cells showing normal size and cell structure. (b) Early apoptotic cells after $24 \mathrm{~h}$ treatment showing chromatin condensation and membrane blebbing. (c) Blebbing and cell shrinkage after $48 \mathrm{~h}$ treatment. (d) Membrane blebbing, cell shrinkage, and apoptotic body formation after $72 \mathrm{~h}$ treatment. CC: chromatin condensation, BL: blebbing, CS: cell shrinkage, and AB: apoptotic body.

toxicity of S-GNPs provides new opportunities for the safe delivery and applications in anticancer therapy.

3.4. Morphological Assessment of S-GNPs. Apoptosis was identified with Hoechst 33342 staining time dependently in the treated cells. Staining the 24-hour S-GNPs treated K562 cell exhibited the typical features of apoptosis, such as chromatin condensation and morphology changes, as well as cell shrinkage and membrane blebbing. The 48-hour SGNPs treated cells showed even smaller nuclei; some had peripherally condensed or clumped chromatin, whereas others showed membrane blebbing. Apoptotic bodies formation was more prominent at 72 hours after treatment of S-GNPs. In contrast, the cells in the control group, without treatment, demonstrated normal nuclear and cellular morphology (Figure 7). Lan et al. also showed that AuNPs with an average diameter of $20.5 \mathrm{~nm}$ reduced cell viability of nasopharyngeal carcinoma cell in a concentration-dependant manner by trypan blue assay, especially at high concentration [36].

3.5. Apoptosis Evaluation. In order to quantify the apoptosis, an annexin V-FITC/PI staining experiment was performed to examine the occurrence of phosphatidylserine externalization onto the cell surface. The percentage of annexin V-FITC stained cells, both the early and late apoptotic cells, increased gradually and significantly $(P<0.05)$ in all groups with the time applied, while the percentage of viable cells subsequently decreased gradually (Figure 8). At six hours of treatment, an abundance of cells developed primarily in the early phase of apoptosis $(6.55 \pm 0.75 \%)$, while increasing incubation time of 12 and 24 hours, respectively, induced more cell apoptosis during the late stage $(9.00 \pm 0.33 \%$ and $12.25 \pm 0.25 \%$, resp.) (Table 1).

Similar results in apoptosis enhanced cell death by (-)-epigallocatechin-3-flat gold nanoparticles (EGCG-PNG) 


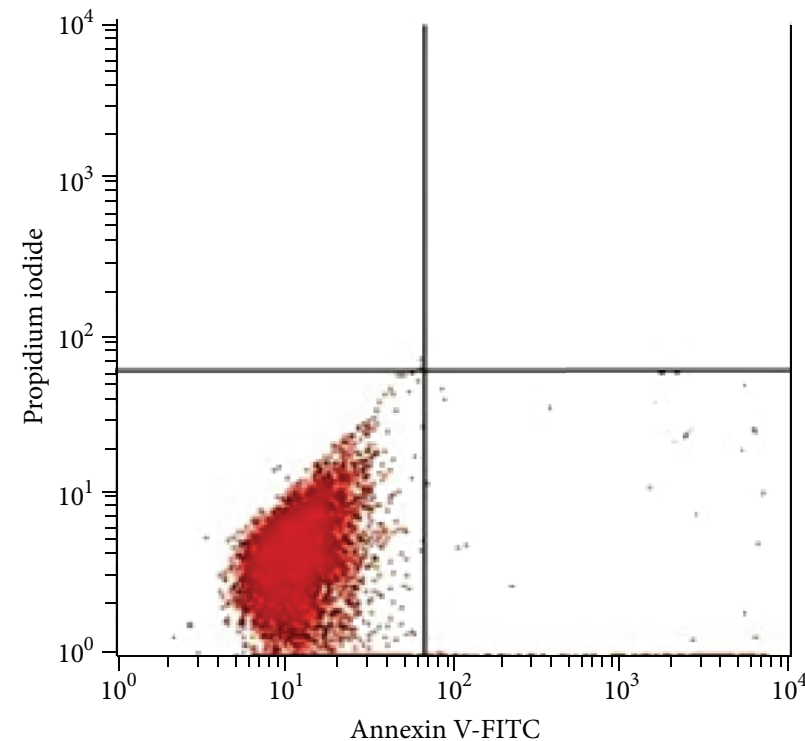

(a)

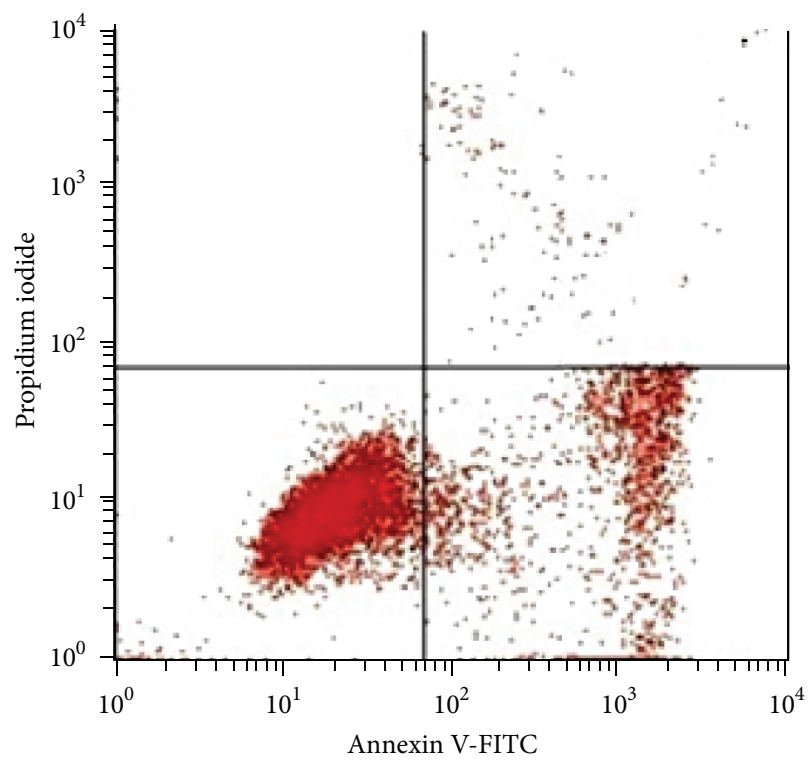

(c)

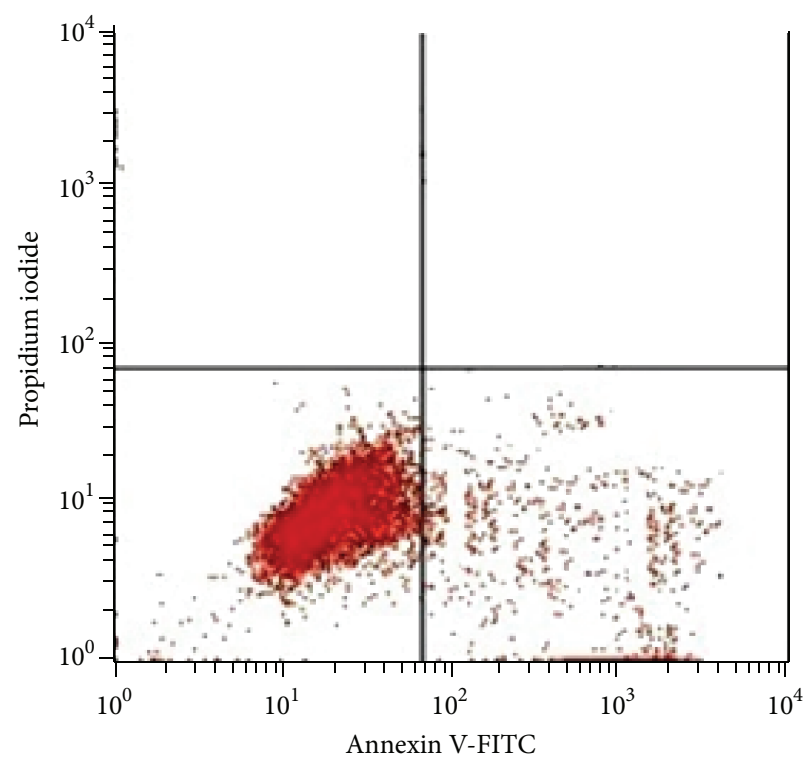

(b)

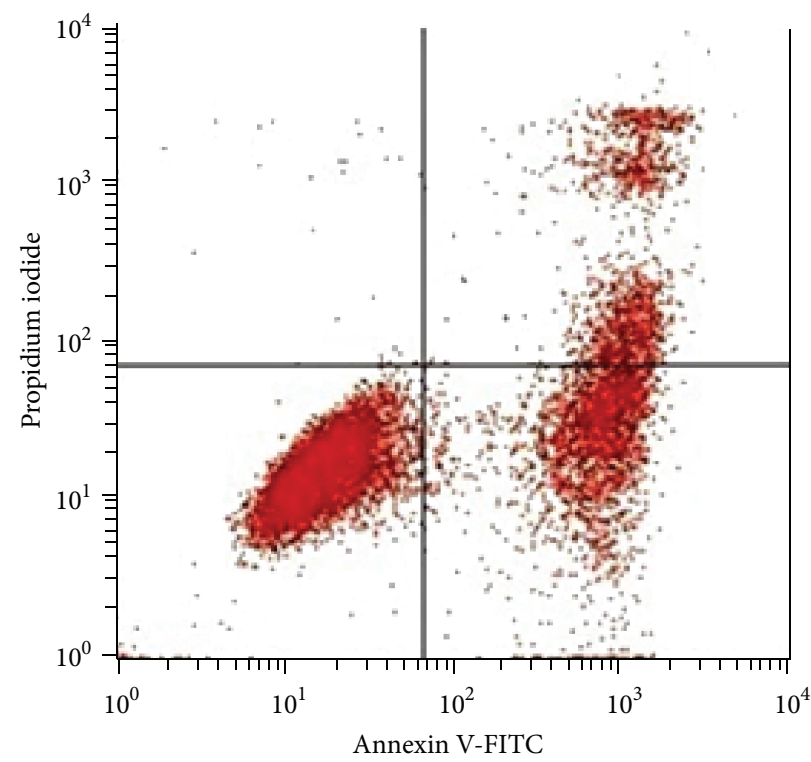

(d)

FIGURE 8: Flow cytometric analysis of apoptosis induction by S-GNPs in K562 cells after staining with FITC-conjugated annexin V and PI. (a) Untreated (control) K562 cells. (b), (c), and (d) Effects of 6, 12, and 24 h S-GNPs treatment, respectively.

were found by other groups in B16F10 murine melanoma cells with increasing fraction of annexin $\mathrm{V}$ positive cells. This, in turn, improved the anticancer efficacy of (-)-epigallocatechin-3-flat gold nanoparticles in murine B16F10 melanoma cells.

3.6. Cell Cycle Analysis. It demonstrated that the untreated cells showed normal DNA content and cell cycle distribution. On the other hand, S-GNPs induced a concomitant and significant $(P<0.05)$ accumulation of K562 cell populations with an apoptotic peak in the SubG0/G1 phase especially at 48 hours of treatment $(6.69 \pm 0.56 \%)$. Moreover, S-GNPs induced cell cycle arrest in the G2/M phase with values of $27.14 \pm$ $0.41 \%, 30.47 \pm 0.35 \%$, and $33.83 \pm 0.93 \%$ after 12,24 , and 48 hours of treatment, respectively (Figure 9 and Table 2).

Huang et al. demonstrated that AuNPs with surface modification, using polyethylene glycol (PEG-AuNPs), inhibited the viability of human chronic myeloid leukemia K562 cells. These particles caused morphological changes typical of cell death, and a marked increase in the sub-G1 population in DNA histogram, indicating apoptosis. In addition, PEGAuNPs reduced the mitochondrial transmembrane potential, a hallmark of the involvement of the intrinsic apoptotic pathway in K562 cells [37]. 
TABLE 2: Flowcytometric analysis of K562 cells after being treated with S-GNPs. The cells were stained with PI and incubated at $37^{\circ} \mathrm{C}$ for 12 , 24 , and $48 \mathrm{~h}$.

\begin{tabular}{lcccc}
\hline Cell cycle phases & & & Cells \% & \\
& Control & Treated/12h & Treated/24h & Treated/48h \\
\hline G0/G1 & $54.33 \pm 0.06$ & $51.36 \pm 0.45$ & $50.56 \pm 0.52$ & $47.10 \pm 0.68$ \\
G2/M & $22.52 \pm 0.76^{*}$ & $27.14 \pm 0.41^{*}$ & $30.47 \pm 0.35^{*}$ & $33.83 \pm 0.93^{*}$ \\
Synthesis & $15.26 \pm 0.06$ & $18.22 \pm 0.33$ & $14.97 \pm 0.12$ & $13.11 \pm 0.18$ \\
Sub-G0/G1 & $1.49 \pm 0.23$ & $3.39 \pm 0.28^{* *}$ & $4.73 \pm 0.20^{* *}$ & $6.69 \pm 0.56^{* *}$ \\
\hline
\end{tabular}

Values are expressed as mean \pm SD of three different experiments. The data has been analyzed using post hoc comparison test-one way ANOVA, means compared with Tukey's- $b$ test. $(*)$ : significant $(P<0.05)$ increased cells in G2/M phase in S-GNPs treated groups compared to untreated controls. $(* *)$ : significant $(P<0.05)$ increased of apoptotic cells in sub-G0/G1 phase in S-GNPs treated groups compared to untreated controls.

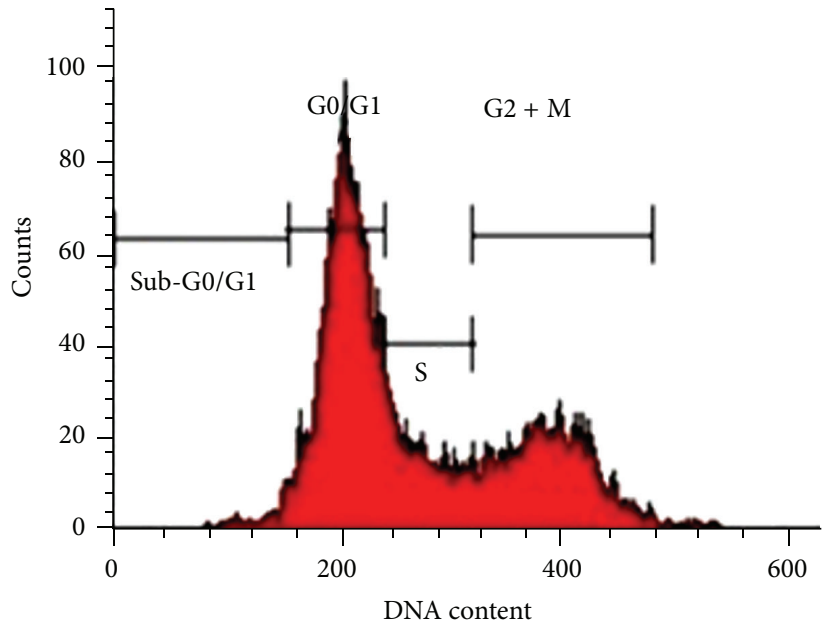

(a)

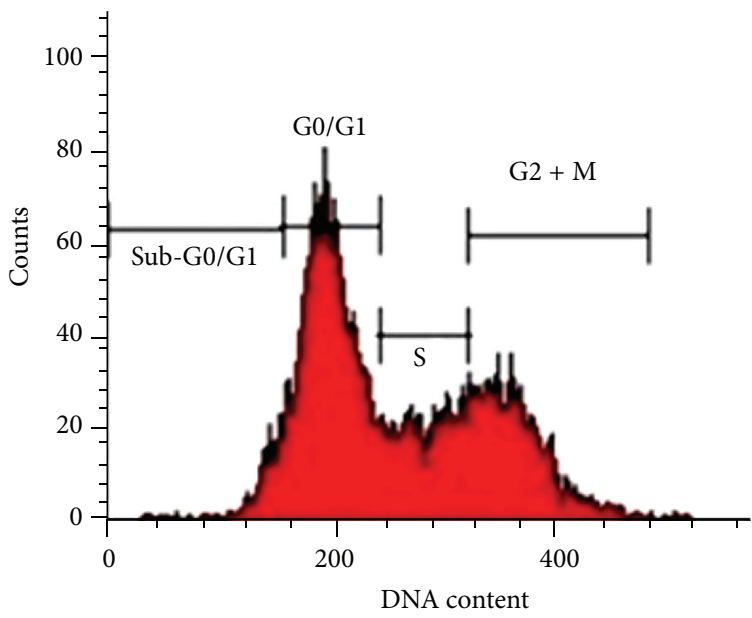

(c)

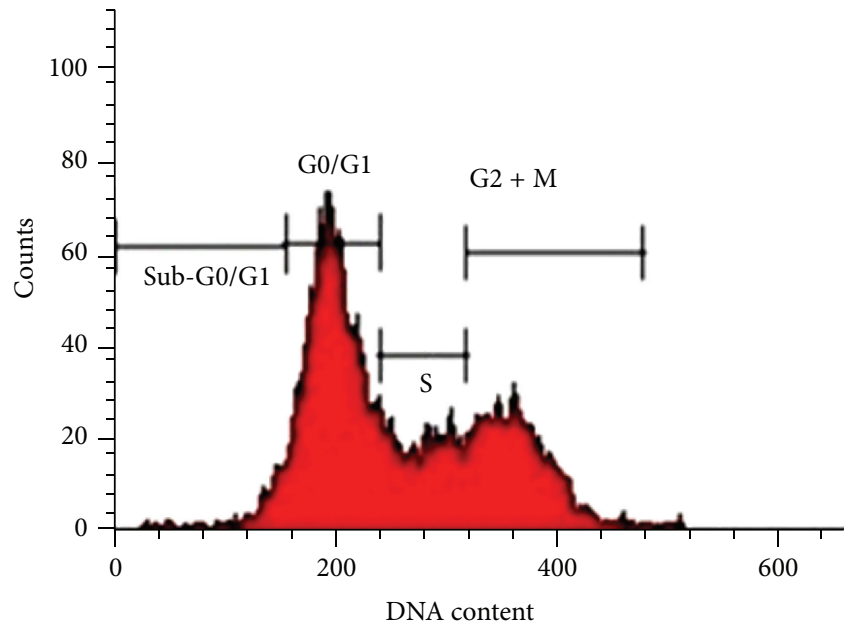

(b)

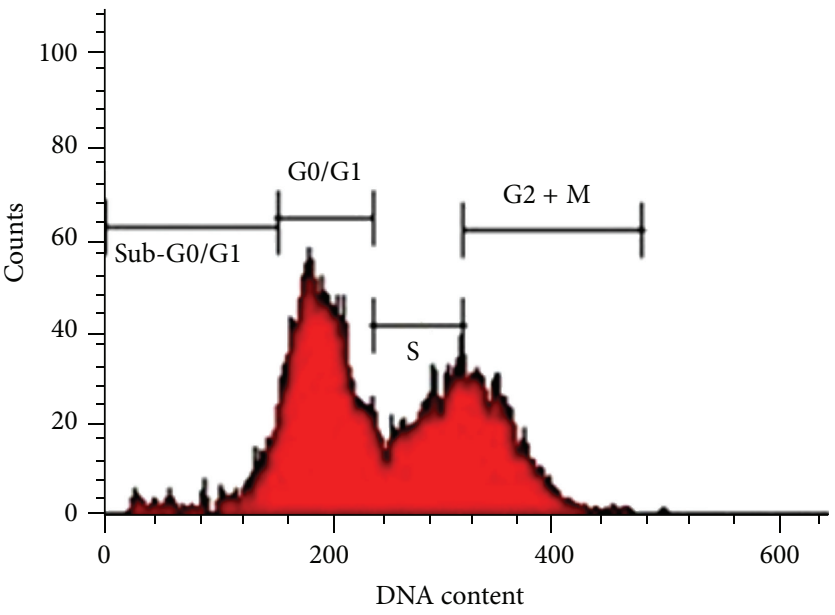

(d)

FIGURE 9: Cell cycle analysis of K562 cells treated with S-GNPs after staining with PI. (a) Untreated (control) K562 cells. (b), (c), and (d) Effects of 12, 24, and 48 h, respectively, exposure of K562 cells to S-GNPs. G0/G1, G2/M, and S indicate the cell phase, and sub-G0-G1 refers to the portion of apoptotic cells.

3.7. Caspase Activity. To investigate the involvement of caspases signaling cascade in S-GNPs induced apoptosis, K562 cells were treated for various times and protease enzymatic activities were determined. S-GNPs significantly $(P<0.05)$ stimulated both caspases 3 and 9 enzyme activities with more than onefold activity in a time-dependent manner in the treated K562 cells, compared to untreated control groups (Figure 10 and Table 3 ). Similar results of caspase protease activity were found in other types of nanoparticles, such as lipid nanoparticles, by Rahman et al. in human lymphoblastoid leukemia Jurkat cells after treatment with zerumbone-loaded nanostructured lipid carrier (ZER-NLC). 
TABLE 3: Caspases spectrophotometric analysis of K562 cells after being treated with S-GNPs for 24 and 48 h, respectively.

\begin{tabular}{|c|c|c|c|c|}
\hline \multirow{2}{*}{ Caspase } & \multicolumn{4}{|c|}{ Cells \% } \\
\hline & Control/24 h & Treated $/ 24 \mathrm{~h}$ & Control/48 h & Treated $/ 48 \mathrm{~h}$ \\
\hline Caspase-3 & $0.055 \pm 0.035$ & $0.15 \pm 0.03^{*}$ & $0.077 \pm 0.041$ & $0.20 \pm 0.009^{*}$ \\
\hline Caspase- 9 & $0.061 \pm 0.071$ & $0.17 \pm .005^{*}$ & $0.079 \pm 0.007$ & $0.22 \pm 0.0055^{*}$ \\
\hline
\end{tabular}

Values are expressed as mean \pm SD of three different experiments. The data has been analyzed using post hoc comparison test-one way ANOVA, means compared with Tukey's- $b$ test. $(*)$ : significant $(P<0.05)$ increase of apoptotic cells in S-GNPs treated groups compared untreated controls.

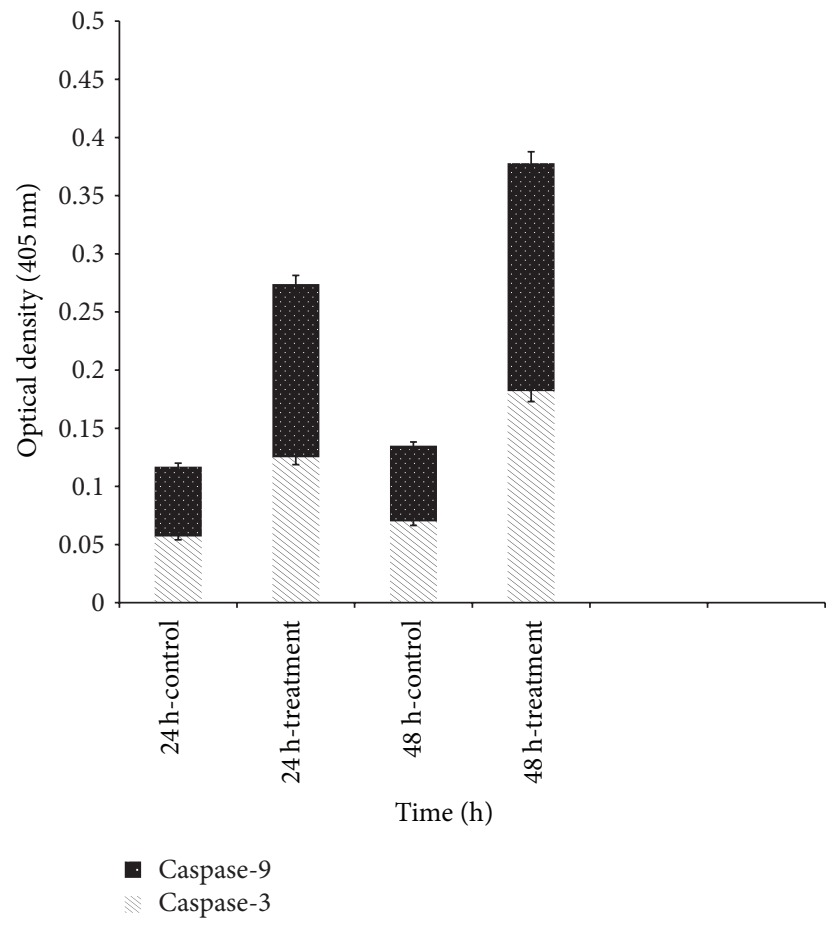

FIGURE 10: Effect of S-GNPs treatment on K562 cell caspases 3 and 9. The values are mean \pm SD of three independent experiments. Significant differences $(P<0.05)$ between treated and control groups for caspases 3 and 9 are found.

Taken together, this is the first report that S-GNPs induced an antiproliferative effect on human blood cancer cells through mitochondrial disruption, leading to cell cycle arrest at the G2/M phase, and subsequently apoptotic cell death.

\section{Conclusion}

Most chemotherapeutics for the treatment of cancers are plagued with toxic side-effects, which too often prove fatal. S-GNPs do not show these side-effects nor do they affect normal cells adversely. Our results showed that S-GNPs possess selective cytotoxicity towards human leukemia cells, which induce apoptosis in a time-dependent manner. The apoptogenic effect of S-GNPs appears to occur via the mitochondrial intrinsic pathway through caspases 3 and 9 activation. Thus, S-GNPs can be further developed into a safe therapeutic compound, for the treatment of not only leukemias, but also other cancers.
However, fucoxanthin is considered to be the most active compound in the S. muticum extract, in which the majority of anticancer activity may be due to its activity, but the process of isolating more active ingredient from the extract should be done in a near future. On the other hand, the acute and chronic toxicity of S-GNPs is in the process of evaluation to confirm the safety of this new drug to be further used for treating of human ailments.

\section{Conflict of Interests}

All authors declare no conflict of interests.

\section{Acknowledgments}

The authors are grateful to the staff of the Institute of Tropical Forestry and Forest Products (INTROP) and Institute of Bioscience (IBS), Universiti Putra Malaysia (UPM), for their kind help and support of this study.

\section{References}

[1] R. Siegel, D. Naishadham, and A. Jemal, "Cancer statistics, 2012," CA: A Cancer Journal for Clinicians, vol. 62, no. 1, pp. 10-29, 2012.

[2] W. Cai, T. Gao, H. Hong, and J. Sun, "Applications of gold nanoparticles in cancer nanotechnology," Nanotechnology, Science and Applications, vol. 1, pp. 17-32, 2008.

[3] Y. Park, Y. N. Hong, A. Weyers, Y. S. Kim, and R. J. Linhardt, "Polysaccharides and phytochemicals: a natural reservoir for the green synthesis of gold and silver nanoparticles," IET Nanobiotechnology, vol. 5, no. 3, pp. 69-78, 2011.

[4] S. Jain, D. G. Hirst, and J. M. O’Sullivan, "Gold nanoparticles as novel agents for cancer therapy," British Journal of Radiology, vol. 85, no. 1010, pp. 101-113, 2012.

[5] S. Sunkar and C. V. Nachiyar, "Synthesis and characterization of biologically synthesized antibacterial silver nanoparticles using the endophytic bacterium Bacillus cereus: a novel source in the Benign synthesis," Global Journal of Medical Research, vol. 12, no. 2, pp. 42-50, 2012.

[6] X. Li, H. Xu, Z.-S. Chen, and G. Chen, "Biosynthesis of nanoparticles by microorganisms and their applications," Journal of Nanomaterials, vol. 2011, Article ID 270974, 16 pages, 2011.

[7] M. Gericke and A. Pinches, "Microbial production of gold nanoparticles," Gold Bulletin, vol. 39, no. 1, pp. 22-28, 2006.

[8] L. Liu, M. Heinrich, S. Myers, and S. A. Dworjanyn, "Towards a better understanding of medicinal uses of the brown seaweed Sargassum in traditional Chinese medicine: a phytochemical and pharmacological review," Journal of Ethnopharmacology, vol. 142, no. 3, pp. 591-619, 2012. 
[9] F. Namvar, P. M. Tahir, R. Mohamad et al., "Biomedical properties of edible seaweed in cancer therapy and chemoprevention trials: a review," Natural Product Communications, vol. 8, no. 12, pp. 1811-1820, 2013.

[10] F. Namvar, S. Mohamed, S. G. Fard et al., "Polyphenol-rich seaweed (Eucheuma cottonii) extract suppresses breast tumour via hormone modulation and apoptosis induction," Food Chemistry, vol. 130, no. 2, pp. 376-382, 2012.

[11] A. A. El Gamal, "Biological importance of marine algae," Saudi Pharmaceutical Journal, vol. 18, no. 1, pp. 1-25, 2010.

[12] F. Namvar, J. Baharara, and A. A. Mahdi, "Antioxidant and anticancer activities of selected persian gulf algae," Indian Journal of Clinical Biochemistry, vol. 29, no. 1, pp. 13-20, 2013.

[13] M. N. A. Khan, J. S. Choi, M. C. Lee et al., "Anti-inflammatory activities of methanol extracts from various seaweed species," Journal of Environmental Biology, vol. 29, no. 4, pp. 465-469, 2008.

[14] A. W. Zuercher, R. Fritsché, B. Corthésy, and A. Mercenier, "Food products and allergy development, prevention and treatment," Current Opinion in Biotechnology, vol. 17, no. 2, pp. 198203, 2006.

[15] G. R. M. Perez, S. M. A. Zavala, G. S. Perez, and G. C. Perez, "Antidiabetic effect of compounds isolated from plants," Phytomedicine, vol. 5, no. 1, pp. 55-75, 1998.

[16] T. Nishino, A. Fukuda, T. Nagumo, M. Fujihara, and E. Kaji, "Inhibition of the generation of thrombin and factor Xa by a fucoidan from the brown seaweed Ecklonia kurome," Thrombosis Research, vol. 96, no. 1, pp. 37-49, 1999.

[17] K. Miyashita, "The carotenoid fucoxanthin from brown seaweed affects obesity," Lipid Technology, vol. 21, no. 8-9, pp. 186190, 2009.

[18] S. Mohamed, S. N. Hashim, and H. A. Rahman, "Seaweeds: a sustainable functional food for complementary and alternative therapy," Trends in Food Science and Technology, vol. 23, no. 2, pp. 83-96, 2012.

[19] K. Wada, K. Nakamura, Y. Tamai et al., "Seaweed intake and blood pressure levels in healthy pre-school Japanese children," Nutrition Journal, vol. 10, no. 1, article 83, 2011.

[20] A. Bocanegra, S. Bastida, J. Benedí, S. Ródenas, and F. J. Sánchez-Muniz, "Characteristics and nutritional and cardiovascular-health properties of seaweeds," Journal of Medicinal Food, vol. 12, no. 2, pp. 236-258, 2009.

[21] I. A. Brownlee, A. Allen, J. P. Pearson et al., "Alginate as a source of dietary fiber," Critical Reviews in Food Science and Nutrition, vol. 45, no. 6, pp. 497-510, 2005.

[22] I. Brownlee, A. Fairclough, A. Hall, and J. Paxman, Dietary Seaweed and Human Health, Centre for Food Innovation, Sheffield Hallam University, Sheffield, UK, 2011.

[23] J. H. Fitton, "Therapies from fucoidan; multifunctional marine polymers," Marine Drugs, vol. 9, no. 10, pp. 1731-1760, 2011.

[24] C. Gerhauser, "Cancer chemoprevention and nutri-epigenetics: state of the art and future challenges," Topics in Current Chemistry, vol. 329, pp. 73-132, 2013.

[25] F. Namvar, S. Azizi, M. B. Ahmad et al., "Green synthesis and characterization of gold nanoparticles using the marine macroalgae Sargassum muticum," Research on Chemical Intermediates, vol. 41, no. 8, pp. 5723-5730, 2015.

[26] R. Zahra, M. Mehrnaz, V. Farzaneh, and S. Kohzad, "Antioxidant activity of extract from a brown alga, Sargassum boveanum," African Journal of Biotechnology, vol. 6, no. 24, pp. 27402745, 2007.
[27] P. Matanjun, S. Mohamed, N. M. Mustapha, and K. Muhammad, "Nutrient content of tropical edible seaweeds, Eucheuma cottonii, Caulerpa lentillifera and Sargassum polycystum," Journal of Applied Phycology, vol. 21, no. 1, pp. 75-80, 2009.

[28] K. H. Wong and P. C. K. Cheung, "Nutritional evaluation of some subtropical red and green seaweeds: part I-proximate composition, amino acid profiles and some physico-chemical properties," Food Chemistry, vol. 71, no. 4, pp. 475-482, 2000.

[29] S. L. Holdt and S. Kraan, "Bioactive compounds in seaweed: functional food applications and legislation," Journal of Applied Phycology, vol. 23, no. 3, pp. 543-597, 2011.

[30] J. Ortiz, N. Romero, P. Robert et al., "Dietary fiber, amino acid, fatty acid and tocopherol contents of the edible seaweeds Ulva lactuca and Durvillaea antarctica," Food Chemistry, vol. 99, no. 1, pp. 98-104, 2006.

[31] P. Kumari, M. Kumar, V. Gupta, C. R. K. Reddy, and B. Jha, "Tropical marine macroalgae as potential sources of nutritionally important PUFAs," Food Chemistry, vol. 120, no. 3, pp. 749757, 2010.

[32] S. Pandey and G. Oza, "Green synthesis of highly stable gold nanoparticles using Momordica charantia as nano fabricator," Archives of Applied Science Research, vol. 4, no. 2, pp. 1135-1141, 2012.

[33] S. Saha, A. Pal, S. Kundu, S. Basu, and T. Pal, "Photochemical green synthesis of calcium-alginate-stabilized Ag and Au nanoparticles and their catalytic application to 4-nitrophenol reduction," Langmuir, vol. 26, no. 4, pp. 2885-2893, 2010.

[34] I. Wijesekara, R. Pangestuti, and S.-K. Kim, "Biological activities and potential health benefits of sulfated polysaccharides derived from marine algae," Carbohydrate Polymers, vol. 84, no. 1, pp. 14-21, 2011.

[35] V. Balzani, "Nanoscience and nanotechnology: the bottom-up construction of molecular devices and machines," Pure and Applied Chemistry, vol. 80, no. 8, pp. 1631-1650, 2008.

[36] M.-Y. Lan, Y.-B. Hsu, C.-H. Hsu, C.-Y. Ho, J.-C. Lin, and S.-W. Lee, "Induction of apoptosis by high-dose gold nanoparticles in nasopharyngeal carcinoma cells," Auris Nasus Larynx, vol. 40, no. 6, pp. 563-568, 2013.

[37] Y.-C. Huang, Y.-C. Yang, K.-C. Yang et al., "Pegylated gold nanoparticles induce apoptosis in human chronic myeloid leukemia cells," BioMed Research International, vol. 2014, Article ID 182353, 9 pages, 2014. 

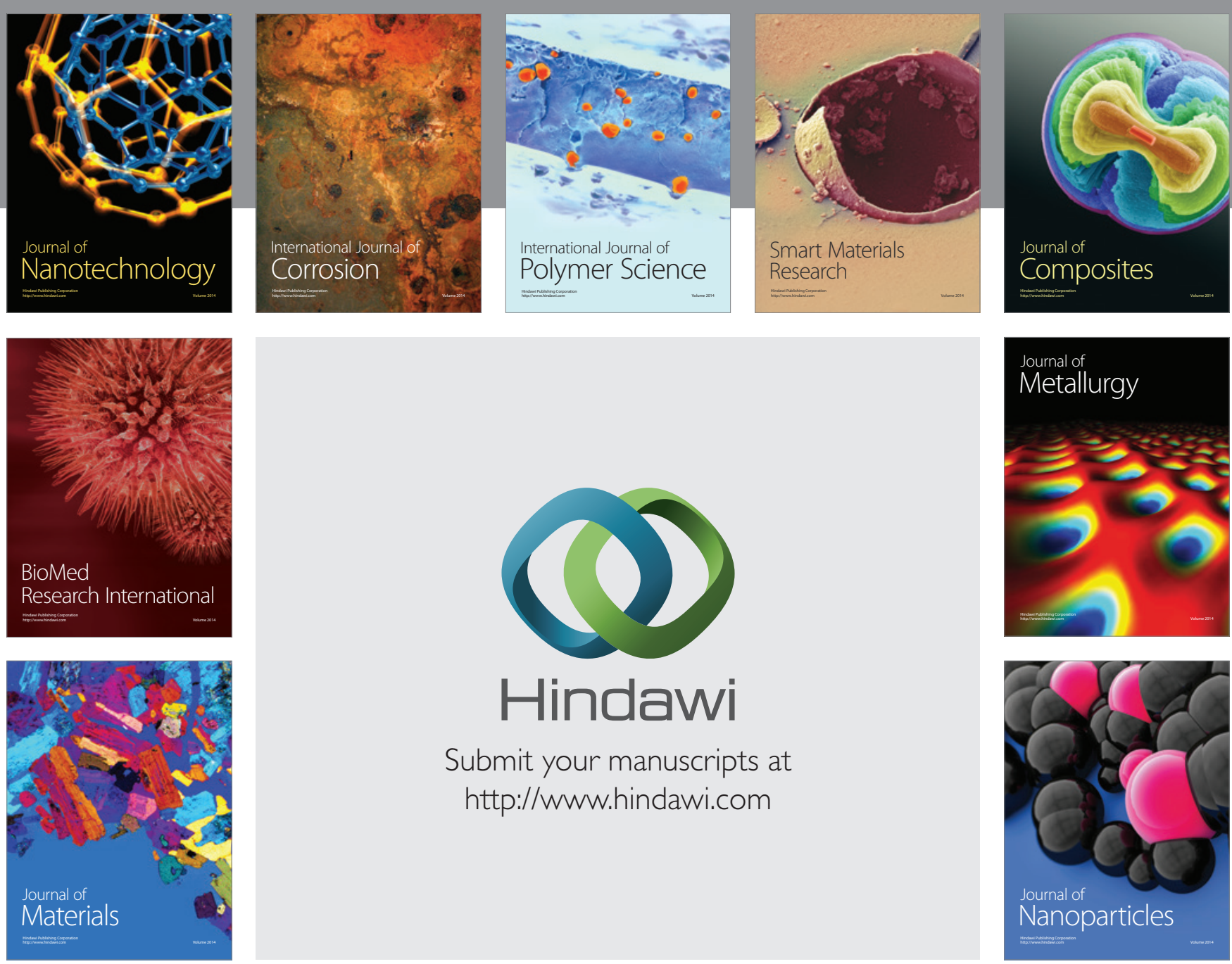

Submit your manuscripts at http://www.hindawi.com
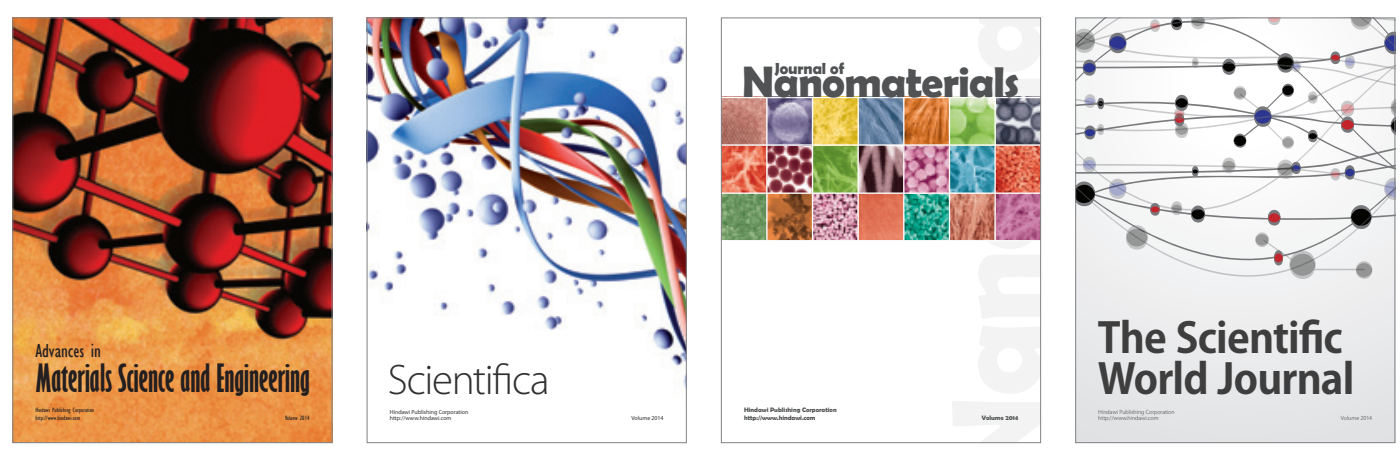

\section{The Scientific World Journal}
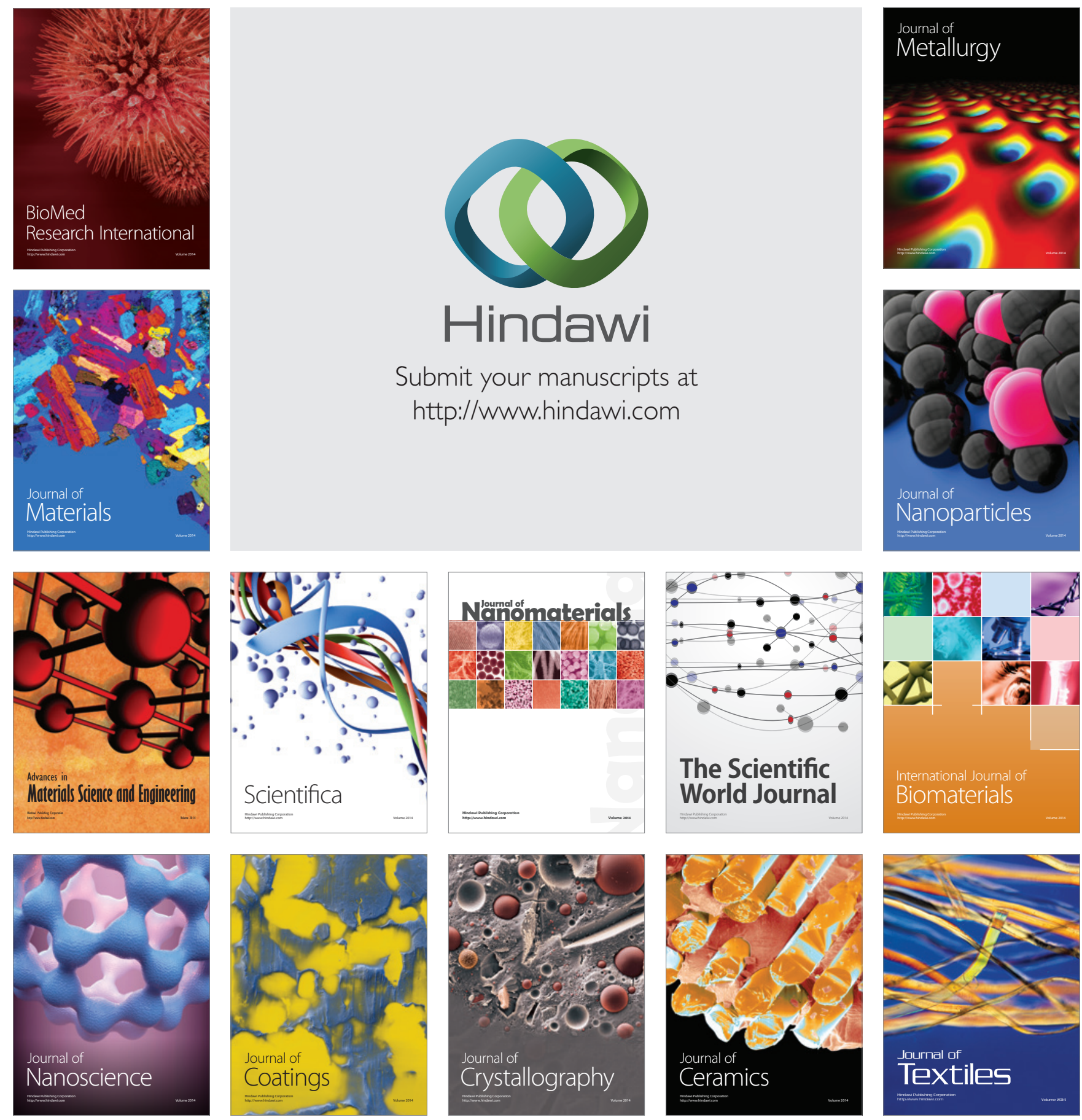